\title{
Viral gametocytic hypertrophy of the Pacific oyster Crassostrea gigas in Ireland
}

\author{
Deborah Cheslett, Frank McKiernan, Cathy Hickey, Evelyn Collins*
}

Fish Health Unit, Marine Institute, Rinville, Oranmore, Co. Galway, Ireland

\begin{abstract}
Viral gametocytic hypertrophy (VGH) was detected during an investigation of mortalities in Pacific oysters Crassostrea gigas from 2 separate Irish production sites. The basophilic inclusions were observed in the gonad tissue of oysters sampled in August and October 2007. The oysters involved did not show any macroscopic disease signs. Transmission electron microscopy demonstrated the presence of viral particles in these intranuclear inclusions. The particles were small, nonenveloped, icosahedral and approximately $50 \mathrm{~nm}$ in diameter, and thus had characteristics similar to the Papillomaviridae and Polyomaviridae families. No host defence reaction was observed. The viral particles described here appear to be similar to those described in C. virginica from the USA and Canada and to those described in C. gigas from Korea and France.
\end{abstract}

KEY WORDS: Crassostrea gigas · Viral gametocytic hypertrophy $\cdot$ Papillomaviridae Polyomaviridae Pacific oyster · Gonad

Resale or republication not permitted without written consent of the publisher

\section{INTRODUCTION}

Numerous viruses can infect molluscs, and mortalities have been reported in different bivalve species associated with the presence of viruses belonging to various families (Elston 1997, Renault \& Novoa 2004). Viruses described in bivalves have included members of the families Herpesviridae, Reoviridae, Picornaviridae, Retroviridae, Birnaviridae, Iridoviridae and Papovaviridae. The family Papovaviridae originally comprised the 2 genera Papillomavirus and Polyomavirus, but they are now considered as 2 separate families Papillomaviridae and Polyomaviridae (Van Regenmortel et al. 2000). These 2 families share morphological characteristics: viruses are non-enveloped, icosahedral and approximately 40 to $55 \mathrm{~nm}$ in diameter (Garcia et al. 2006).

Farley (1985) observed viral gametocytic hypertrophy (VGH) in hypertrophied cells of gonad tubules of Crassostrea virginica sampled in various US states but extensively in Maine. He described non-enveloped, icosahedral viral particles 50 to $55 \mathrm{~nm}$ in diameter in the maturing and mature cells. He also reported on histologically similar lesions seen in C. gigas and Ostrea lurida from Korea, Japan, Oregon and Washington and similar lesions in C. rhizophorae from Puerto Rico. Similar viral particles have also been described from $C$. virginica from the east coast of North America (Sparks 1985), the Gulf of Mexico (Winstead et al. 1998, Winstead \& Courtney 2003) and Atlantic Canada (McGladdery \& Stephenson 1994). Bower et al. (1994) reported the presence of viral particles with massive gamete hypertrophy in C. virginica from Atlantic Canada and the eastern United States; infection rates were generally low and there was no indication of associated mortalities.

Basophilic inclusions associated with VGH were described in the gonad tissue of Crassostrea gigas in southern Korea and, from electron microscopic observations, appeared to match the size range described for the polyomaviruses (Choi et al. 2004). Viral particles with characteristics similar to the Papillomaviridae and Polyomaviridae families have also been reported in C. gigas in France (Garcia et al. 2006). Moss et al. (2007) observed VGH histologically in the gonad of wild C. hongkongensis during a survey of Asian oysters for pathogens. Watermann et al. (2008) observed VGH in the hypertrophied gametocytes of $C$. gigas during investigations in to the health condition of these oysters along the East Frisian coast of Germany. 
The actual impact of papilloma-like and polyomalike viruses on their hosts has not been fully assessed (Garcia et al. 2006). Neither is it clearly understood whether one or more viruses are involved in these gonad conditions. In 2007, we observed VGH in Crassostrea gigas gonad tissue sampled from 2 separate production sites in Ireland. We reprocessed the waxembedded oyster gonad tissue for electron microscopy and describe the ultrastructure of the viral particles observed in these infected oysters.

\section{MATERIALS AND METHODS}

From August to October 2007, following reports of increased levels of mortalities, a total of 77 marketsized Crassostrea gigas were collected from 2 separate production sites in Ireland: Site A (County Kerry) and Site B (County Donegal) (Fig. 1).

Histological examination. Oyster tissue fixed in $10 \% \mathrm{v} / \mathrm{v}$ formalin solution was processed for routine histology. Sections were cut at $2 \mu \mathrm{m}$ and stained with haematoxylin and eosin (H\&E).

Ultrastructural examination. When inclusion bodies were observed during light microscopy, the waxembedded oyster tissue containing the inclusion was reprocessed for transmission electron microscopy (TEM) as follows. With the H\&E-stained section as a visual guide, the portion of wax-embedded tissue with the

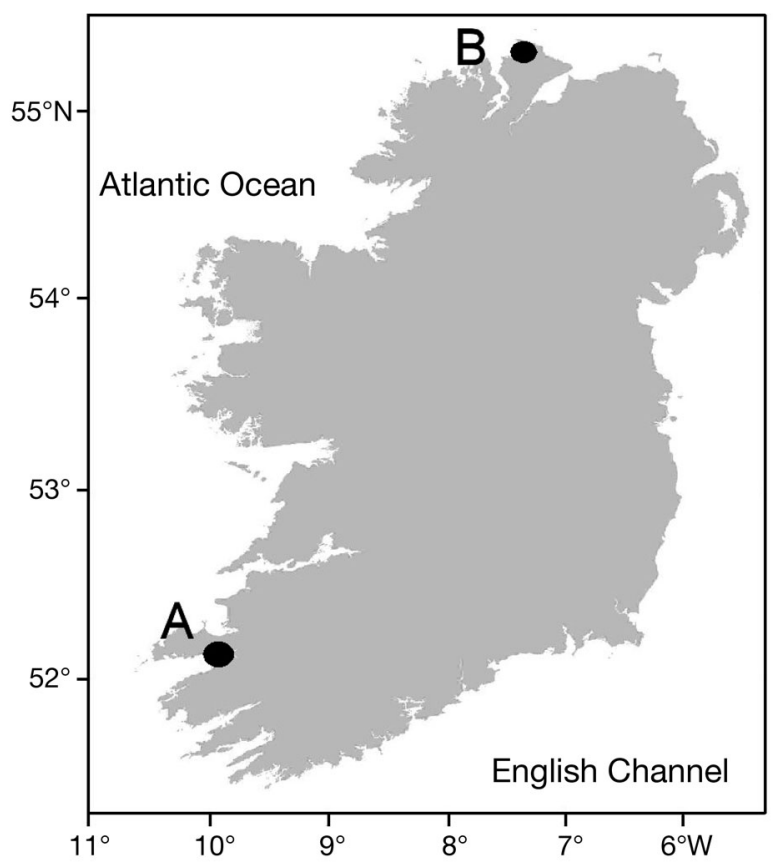

Fig. 1. Sample locations of infected Crassostrea gigas in Ireland collected between August and October 2007. Site A: County Kerry; Site B: County Donegal inclusion was removed with a scalpel from the wax block and dewaxed overnight in 2 changes of xylene with agitation. Following rehydration, the tissue was then placed in $3 \%$ glutaraldehyde in $0.1 \mathrm{M}$ cacodylate buffer ( $\mathrm{pH} 7.4$ ) for 2 to $5 \mathrm{~h}$, rinsed again in $0.1 \mathrm{M}$ cacodylate buffer and finally post-fixed in $1 \% \mathrm{OsO}_{4}$ for $2 \mathrm{~h}$. After dehydration through graded alcohols, the tissues were infiltrated with a 1:1 solution of Agar low viscosity resin and $50 \%$ ethanol with agitation for $1 \mathrm{~h}$, followed by $100 \%$ resin for $2 \mathrm{~h}$ minimum. Tissues were embedded in resin and cured at $60^{\circ} \mathrm{C}$ for 2 to $3 \mathrm{~d}$. Semithin sections were stained with $1 \%$ toluidine blue and ultra-thin sections were stained with uranyl acetate and lead citrate. Ultra-thin sections were viewed using a Hitachi H-7500 transmission electron microscope at $75 \mathrm{kV}$.

\section{RESULTS}

No gross clinical disease signs were observed in the Crassostrea gigas collected from Site A (County Kerry) or Site B (County Donegal) between August and October 2007. In H\&E-stained sections, basophilic inclusions were observed in hypertrophied nuclei in 2 of 53 oysters sampled from Site A during August and October, and in 1 of 24 oysters sampled from Site B in August. Infected maturing and mature ovocytes showed hypertrophied nuclei with perinuclear condensed nuclear material (Fig. 2).

There was no haemocytic infiltration or other host tissue reaction observed associated with the infection. TEM of reprocessed wax-embedded tissue containing the basophilic inclusions demonstrated that the granular inclusions consisted of a homogeneous amalga-

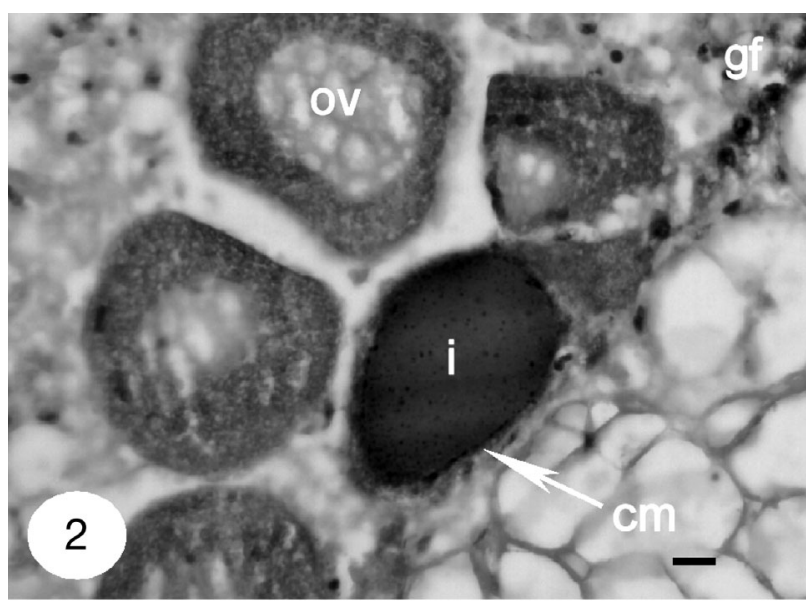

Fig. 2. Crassostrea gigas. Basophilic intranuclear inclusion in a gonad follicle of the oyster. Light micrograph of oyster gonad follicle (gf). Inclusion (i) and perinuclear condensed material ( $\mathrm{cm}$, arrow) in the nucleus of an ovocyte (ov). $\mathrm{H} \& \mathrm{E}$ staining. Scale bar $=10 \mu \mathrm{m}$ 
mation of viral particles. The nuclear membrane of the infected ovocyte was normal and peripherally displaced chromatin could be observed (Fig. 3). The viral particles were approximately 45 to $50 \mathrm{~nm}$ in diameter and non-enveloped (Fig. 4). They were 5- or 6-sided, suggesting an icosahedral symmetry (Fig. 5). Under TEM the viral particles from both sites appeared to be similar.

During the sampling period, 8 aquaculture sites experienced mortalities in Site A and cumulative mortalities ranged from 10 to $40 \%$. In Site B, 4 operators noted mortalities of approximately $30 \%$. From a total of 77 oysters examined, only 3 female oysters were found to have basophilic inclusions, with the number of infected cells ranging from 3 to 14 per section.

Based on the reprocessed TEM material, although of reduced quality, these viral particles appear similar to

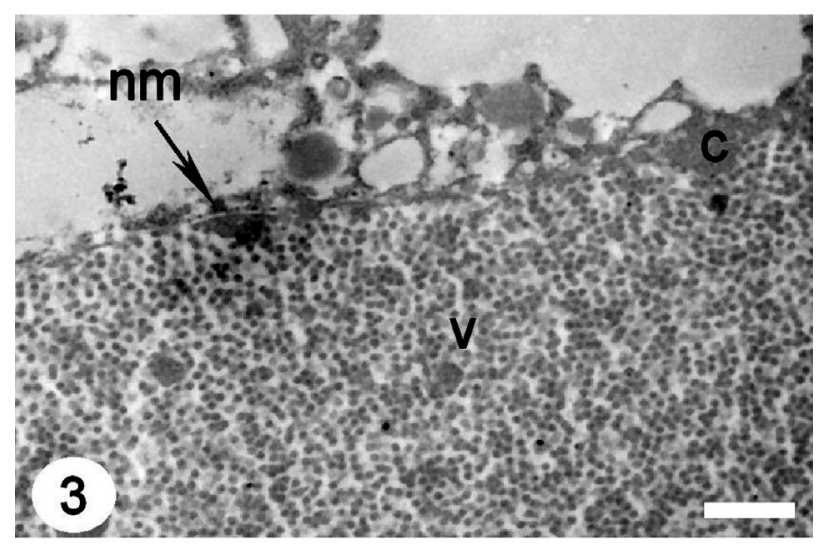

Fig. 3. Crassostrea gigas. Ultrathin section of inclusion body, showing intranuclear viral particles (v) in an ovocyte with a normal nuclear membrane (nm, arrow) and chromatin mass (c). Scale bar $=500 \mathrm{~nm}$

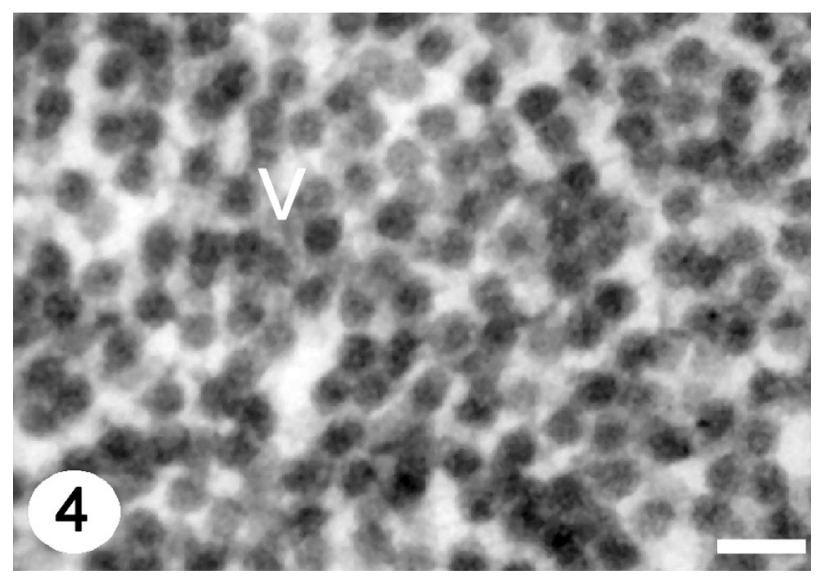

Fig. 4. Crassostrea gigas. Ultrathin section of inclusion body showing details of viral particles (v), which are nonenveloped, icosahedral and 45 to $50 \mathrm{~nm}$ in diameter. Scale bar $=100 \mathrm{~nm}$

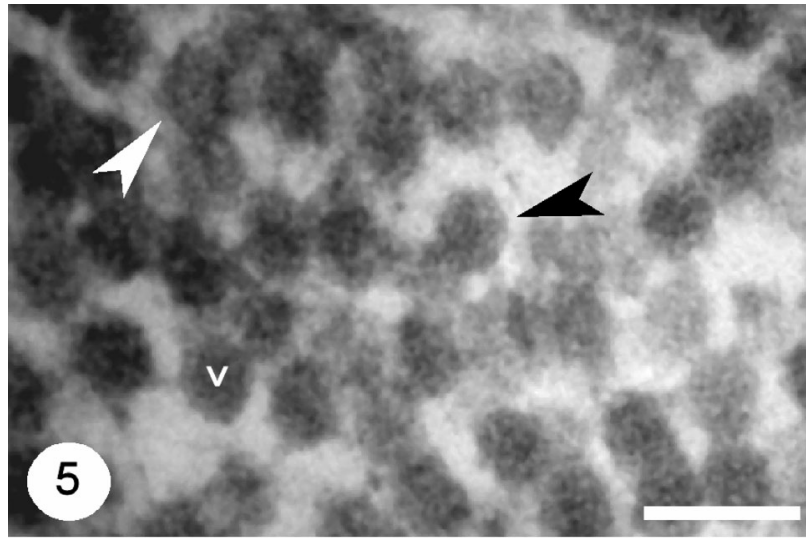

Fig. 5. Crassostrea gigas. Intranuclear 5-sided (white arrowhead) and 6-sided (black arrowhead) viral particles (v) in an ovocyte. Scale bar = $100 \mathrm{~nm}$

those described by Winstead \& Courtney (2003), Choi et al. (2004) and Garcia et al. (2006).

\section{DISCUSSION}

Farley (1976, 1985) described a papova-like virus in hypertrophied gametocytes of the eastern oyster Crassostrea virginica; since then other authors have reported similar conditions in various oyster species in North America, Asia and Europe (McGladdery \& Stephenson 1994, Elston 1997, Choi et al. 2004, Garcia et al. 2006). This is the first report of VGH in C. gigas in Ireland. Observations at the ultrastructural level in the present study show that the basophilic inclusions seen in histology are in fact large masses of viral particles in the hypertrophied nuclei of gonad tissue. The size and symmetry of these particles suggest similarity to the Papillomaviridae and Polyomaviridae families (Van Regenmortel et al. 2000); however, further studies would be required to formally assign the viral particles to these families.

Papilloma- and papova-like viruses have been described from various bivalve species (Elston 1997). However, without the availability of molluscan cell lines, none of these viruses have been isolated and characterised, and insufficient knowledge is available from histopathological and ultrastructural studies alone to discriminate between these viruses described from various parts of the world.

Although VGH is readily detected in maturing gametes, it is more difficult to detect in non-mature oysters (Garcia et al. 2006). A maximum infection level of 350 cells (average of 4 infected cells per section) was reported in Crassostrea virginica by Farley (1985), who also noted that female oysters were more often in- 
fected. Garcia et al. (2006) observed up to 16 infected cells per section in C. gigas, and also noted that $C$. gigas male and female oysters were equally affected by VGH. However, Watermann et al. (2008) observed up to 20 infected cells per section in C. gigas, and reported that male oysters were more commonly infected. These author also noted that, even though there had been previous surveys carried out along the East Frisian coast in 2003 and 2004, VGH had not been detected, as was also the case in France before 2001 (Garcia et al. 2006). In the present study we observed between 3 and 14 infected cells per section in 3 female oysters; however, the number of oysters examined is too low to establish infection rate or infection intensity.

In common with other studies (Choi et al. 2004, Garcia et al. 2006), no haemocytic reaction was observed in the present study, suggesting limited health implications for the infected oysters. However, Garcia et al. (2006) comment that gamete viability and consequently oyster fecundity could be altered by VGH. In the present study the stocks examined were experiencing mortalities, but the low number of oysters detected with VGH and the lack of any clinical disease signs would suggest that the observed virus particles were unlikely to be causing the mortalities. Since 1993, oyster mortalities have been repeatedly experienced during the late summer months in many of the Irish Crassostrea gigas production areas, without the identification of any linked pathogen or pathogens. The mortalities experienced here fit this pattern.

So far no serious manifestations are known for this virus, but the possibility exists for oncogenic transformation (Harshbarger et al. 1979, Farley 1985, Van Regenmortel et al. 2000, Watermann et al. 2008). Potential interspecific cross-infection may produce disease in other, possibly more susceptible, hosts. This would have significant implications, particularly in the case of the introduction of non-native species (Munn 2006, Watermann et al. 2008).

Virus-like particles have been identified in many species of bivalve molluscs (Renault \& Novoa 2004), although proof of aetiology and study of pathogenesis is often lacking (Munn 2006). Viruses may be found in molluscs already debilitated by disease or by other stress factors (Montes et al. 2001). On the other hand, viruses may be observed simply due to bioaccumulation, and their presence may not necessarily imply disease. Infectious disease is a complex interaction between the agent, the host and the environment. It is also necessary to distinguish between viral infection and actual disease manifestation. By definition, a virus is infective for its particular host(s), but may have varying effects on different life stages of the host and may be more virulent for different species (Elston 1997). At present, diagnosis of viral disease is by light micro- scopy followed by confirmation using TEM. The lack of molluscan cell lines has impeded the advancement of bivalve virology, but recently the use of molecular tools has become more widespread (Munn 2006). Cultivation trials, followed by the physical isolation of viruses and the use of genetic probes and other molecular tools, can assist in advancing this field.

Viral diseases are of concern in intensively reared molluscs because no specific chemotherapies or vaccines are available. A better understanding of the virus and virus-host interaction is required for disease control in aquaculture and for reducing the transmission of viral diseases between cultured and natural populations of bivalve molluscs. Advancement in the field of molluscan virology will require increased application of physical isolation methods, the development of continuous molluscan cell lines and the use of molecular tools and should be the focus of further studies.

Acknowledgements. The authors acknowledge and thank the Department of Anatomy and NCBES NUI Galway for the use of their electron microscopy suites, and are very grateful to P. Lalor and N. Donoghue for their advice and assistance with electron microscopy preparations.

\section{LITERATURE CITED}

Bower SM, McGladdery SE, Price IM (1994) Synopsis of infectious diseases and parasites of commercially exploited shellfish. Annu Rev Fish Dis 4:1-199

Choi DL, Lee NS, Choi HJ, Park MA, McGladdery SE, Park MS (2004) Viral gametocytic hypertrophy caused by a papova-like virus infection in the pacific oyster Crassostrea gigas in Korea. Dis Aquat Org 59:205-209

> Elston R (1997) Special topic review: bivalve mollusc viruses. World J Microbiol Biotechnol 13:393-403

> Farley CA (1976) Ultrastructural observations on epizootic neoplasia and lytic virus infection in bivalve molluscs. Prog Exp Tumor Res 20:283-294

Farley CA (1985) Viral gametocyte hypertrophy in oysters. In: Sindermann CJ (ed) Identification leaflets for diseases and parasites of fish and shellfish, No. 25. ICES, Copenhagen, p $1-5$

Garcia C, Robert M, Arzul I, Chollet B and others (2006) Viral gametocytic hypertrophy of Crassostrea gigas in France: from occasional records to disease emergence? Dis Aquat Org 70:193-199

Harshbarger JC, Otto SV, Chang SC (1979) Proliferative disorders in Crassostrea virginica and Mya arenaria from the Chesapeake Bay and intranuclear viral-like inclusions in Mya arenaria with germinomas from a Maine oil spill site. Haliotis 8:243-248

McGladdery SE, Stephenson MF (1993) A viral infection of the gonads of eastern oyster (Crassostrea virginica) from Atlantic Canada. Bull Aquac Assoc Can 93:84-86

> Montes JF, Durfort M, Garcia-Valero J (2001) Parasitism by the protozoan Perkinsus atlanticus favours the development of opportunist infections. Dis Aquat Org 46: 57-66

> Moss JA, Burreson EM, Cordes JF, Dungan CF and others (2007) Pathogens in Crassostrea ariakensis and other 
Asian oyster species: implications for non-native oyster introduction to Chesapeake Bay. Dis Aquat Org 77: 207-223

Munn CB (2006) Viruses as pathogens of marine organisms from bacteria to whales. J Mar Biol Assoc UK 86:453-467

Renault T, Novoa B (2004) Viruses infecting bivalve molluscs. Aquat Living Resour 17:397-409

Sparks AK (1985) Synopsis of invertebrate pathology exclusive of insects. Elsevier Science Publishers, Amsterdam

Van Regenmortel HV, Fauquet CM, Bishop DHL, Carstens EB and others (2000) Virus taxonomy: classification and nomenclature of viruses. Seventh report of the Inter-

Editorial responsibility: Eugene Burreson,

Gloucester Point, Virginia, USA national Committee on Taxonomy of Viruses. Academic Press, San Diego, CA, p 241-251

Watermann BT, Herlyn M, Daehne B, Bergmann S, Meemkemn M, Kolodzey H (2008) Pathology and mass mortality of Pacific oysters, Crassostrea gigas (Thunberg), in 2005 at the East Frisian coast, Germany. J Fish Dis 31:621-630

- Winstead JT, Courtney LA (2003) Ovacystis-like condition in the eastern oyster Crassostrea virginica from the northeastern Gulf of Mexico. Dis Aquat Org 53:89-90

Winstead JT, Overstreet RM, Courtney LA (1998) Novel parasites in the eastern oyster Crassostrea virginica from two Gulf of Mexico bays. J Shellfish Res 17:341-342

Submitted: September 23, 2008; Accepted: December 4, 2008 Proofs received from author(s): February 11, 2009 